Proportion of articles in five medical journals with financial competing interest statements. Values are numbers (percentages)

\begin{tabular}{|c|c|c|c|c|c|}
\hline Sample year & $\begin{array}{l}\text { Annals of } \\
\text { Internal } \\
\text { Medicine }\end{array}$ & BMJ & JAMA & Lancet & $\begin{array}{l}\text { New England } \\
\text { Journal of } \\
\text { Medicine }\end{array}$ \\
\hline \multicolumn{6}{|c|}{ Editorials $(n=412)$ : } \\
\hline 1989 & $0 / 13$ & $0 / 23$ & $0 / 8$ & $0 / 33$ & $0 / 14$ \\
\hline 1994 & $0 / 13$ & $0 / 33$ & $1 / 11(9)$ & $0 / 35$ & $0 / 17$ \\
\hline 1996 & $0 / 12$ & $0 / 32$ & $0 / 12$ & $0 / 40$ & $0 / 11$ \\
\hline 1999 & $1 / 10(10)$ & $2 / 30(7)$ & $3 / 11(27)$ & $0 / 40$ & $0 / 14$ \\
\hline Total & $1 / 48(2)$ & $2 / 118(2)$ & $4 / 42(10)$ & $0 / 148$ & $0 / 56$ \\
\hline \multicolumn{6}{|c|}{ Papers $(n=656)$ : } \\
\hline 1989 & $0 / 28$ & $0 / 51$ & $0 / 26$ & $0 / 26$ & 2/23 (9) \\
\hline 1994 & $0 / 39$ & $0 / 45$ & $2 / 24(8)$ & $0 / 37$ & $0 / 26$ \\
\hline 1996 & $0 / 36$ & $1 / 51(2)$ & $0 / 24$ & $0 / 34$ & $0 / 26$ \\
\hline 1999 & $0 / 33$ & $8 / 37(22)$ & $6 / 27(22)$ & $0 / 37$ & $4 / 26(15)$ \\
\hline Total & $0 / 136$ & $9 / 184(5)$ & $8 / 101$ (8) & $0 / 134$ & $6 / 101(6)$ \\
\hline \multicolumn{6}{|c|}{ Letters $(n=2574)$ : } \\
\hline 1989 & $0 / 71$ & $0 / 172$ & $0 / 101$ & $0 / 262$ & $0 / 120$ \\
\hline 1994 & $0 / 86$ & $1 / 176(<1)$ & $4 / 82(5)$ & $0 / 211$ & $0 / 131$ \\
\hline 1996 & $0 / 66$ & $0 / 167$ & $3 / 85(4)$ & $0 / 205$ & $0 / 113$ \\
\hline 1999 & $0 / 63$ & $8 / 139(6)$ & $5 / 82(6)$ & $1 / 129(<1)$ & $0 / 113$ \\
\hline Total & $0 / 286$ & $9 / 654(1)$ & $12 / 350(3)$ & $1 / 807(<1)$ & $0 / 477$ \\
\hline
\end{tabular}

ments may account for the disparity among journals. For instance, the lack of declarations in New England Journal of Medicine editorials is not surprising as the journal (not always successfully ${ }^{2}$ ) prohibits them being written by authors with financial ties. The Lancet's in-house editorial team always writes the first editorial of each issue, signing it "The Lancet," a style that makes it impossible to know whether contributing authors have competing interests. But subsequent editorials conform to the more common format of naming individual authors at the end of the article, making it possible to request, and thus publish, details of each author's competing interests. The greater proportion of declarations in JAMA editorials may reflect the journal's longstanding policy of requiring authors to sign documents declaring any financial competing interests. The proportion of declarations in $B M J$ papers was much greater in 1999 than 1996. This may reflect the journal's adoption, in 1998, of Stelfox's recommendations requiring authors to answer a series of short questions on their financial ties. ${ }^{5}$

Data in this study have been drawn from information published in journals, and not directly from what authors revealed to editors. There is potential for disparity here, but it is difficult to see why editors would decide against revealing competing interests that were disclosed to them, given what is clearly stated in their policies.

Editors can learn much from examining the policies of other journals and adopting the features that seem conducive to disclosure. Research is needed to verify whether some of the authors who had not made a declaration did in fact have undeclared financial competing interests when they wrote their articles. It would also be useful to know the impact, if any, of competing interest statements on readers.

We thank Julie Morris for statistical advice.

Contributors: AH designed the study, collected the data, and wrote the paper. RS proposed the idea for the study, discussed the interpretation with $\mathrm{AH}$, and corrected the manuscript. $\mathrm{AH}$ is guarantor.

Funding: No additional funding.

Competing interests: RS is the editor of the $B M J$ and responsible for devising its policy on competing interests. He is paid a fixed salary and will not be affected financially by the success or failure of the policy on competing interests.

This study was peer reviewed in the normal way, except that RS played no part in the process.

1 Stelfox HT, Chua G, O'Rourke K, Detsky AS. Conflict of interest in the debate over calcium channel antagonists. N Engl J Med 1998;338:101-5.

2 Monmaney T. Medical journals may have flouted own ethics 8 times. Los Angeles Times 1999 October 21.

3 Krimsky S, Rothenberg LS, Stott P, Kyle G. Scientific journals and their authors' financial interests: a pilot study. Sci Eng Ethics 1996;2:395-410.

4 International Committee of Medical Journal Editors. Conflict of interest. Lancet 1993;341:742-3.

5 Smith R. Beyond conflict of interest. BMJ 1998;317:291-2.

(Accepted 26 March 2001)

\title{
Effect of Helicobacter pylori infection on blood pressure: a community based cross sectional study
}

Richard Harvey, Athene Lane, Liam Murray, Ian Harvey, Prakash Nair, Jenny Donovan

Frenchay Hospital, North Bristol NHS Trust, Bristol BS16 1LE

Richard Harvey consultant gastroenterologist Prakash Nair special lecturer in medicine

continued over

BMJ 2001;323:264-5
Many studies have reported an association between Helicobacter pylori infection and an increased risk of cardiovascular disease. The strength of the association has been hard to judge because of the varied methods of the studies and substantial heterogeneity of the findings. Mechanisms that may contribute to this association include abnormalities in the levels of certain blood proteins (for example fibrinogen or $\mathrm{C}$ reactive protein) secondary to the chronic infection ${ }^{12}$ and raised blood pressure in people infected with H pylori..$^{3-5}$

There are several methodological difficulties in carrying out studies to determine whether $H$ pylori infection results in raised blood pressure. We have attempted to minimise such problems in a large prospective community based study of the association between $H$ pylori infection and blood pressure.

\section{Methods and results}

The Bristol helicobacter project is a community based study centred on the northeastern suburbs of Bristol. The primary aims of the study are to assess the effects of $H$ pylori infection (and its eradication, on a double blind basis) on digestive symptoms and their treatment and on various other aspects of health and quality of life. We have measured blood pressure prospectively in people who were recruited into this study and whose helicobacter status and other risk factors for raised blood pressure were known.

Of the 10537 subjects enrolled in the project, 1634 (15.5\%) were positive for $H$ pylori infection on a ${ }^{13} \mathrm{C}$ urea breath test, using $100 \mathrm{mg}^{13} \mathrm{C}$ urea with a standard orange juice and citric acid test meal and a cut off of $3.5 \delta{ }^{13} \mathrm{C}$ per ml. Blood pressure was measured with a 
Blood pressure $(\mathrm{mm} \mathrm{Hg})$ in subjects with or without Helicobacter pylori infection. Values are means (SD) unless indicated otherwise

\begin{tabular}{|c|c|c|c|c|c|}
\hline & \multirow[b]{2}{*}{$\begin{array}{c}\text { H pylori } \\
\text { positives } \\
(\mathrm{n}=1633)\end{array}$} & \multirow[b]{2}{*}{$\begin{array}{c}H \text { pylori } \\
\text { negatives } \\
(\mathrm{n}=3267)\end{array}$} & \multirow[b]{2}{*}{$\begin{array}{l}\text { Crude difference ( } 95 \% \text { Cl; } \\
\text { P value })^{\star}(\mathrm{n}=4900)\end{array}$} & \multicolumn{2}{|c|}{ Adjusted difference $(95 \% \mathrm{Cl}$; P value $) \dagger$} \\
\hline & & & & $\begin{array}{l}\text { Including participants taking } \\
\text { drugs for hypertensionł } \\
(\mathrm{n}=4483)\end{array}$ & $\begin{array}{l}\text { Excluding participants taking } \\
\text { drugs for hypertension } \\
(\mathrm{n}=4203)\end{array}$ \\
\hline Systolic blood pressure & $121.0(16.5)$ & $119.9(15.9)$ & $1.1(0.13$ to $2.05 ; 0.026)$ & $-1.42(-2.36$ to $-0.49 ; 0.003)$ & $-1.51(-2.47$ to $-0.55 ; 0.002)$ \\
\hline Diastolic blood pressure & $76.8(11.5)$ & $75.8(11.5)$ & 1.0 (0.31 to $1.68 ; 0.004)$ & $-0.18(-0.86$ to $0.51 ; 0.613)$ & $-0.16(-0.86$ to $0.54 ; 0.656)$ \\
\hline
\end{tabular}

*Difference between means of $H$ pylori positive and negative participants.

†Data for some variables not available for all participants.

$\ddagger$ Adjusted for effects of age, sex, body mass index, high alcohol intake, hypertension medication, and smoking.

random-zero sphygmomanometer (Hawksley, Lancing). Participants completed a questionnaire on demographic and lifestyle characteristics, and their height and weight were measured. Blood pressure in 1633 individuals with helicobacter infection was compared with twice that number (3267) of randomly selected non-infected subjects (total 4900). Multiple linear regression models (Stata version 6) were used, with systolic and diastolic blood pressure as the dependent variables, $H$ pylori status as the predictor variable, and the potential confounders as covariables.

Systolic blood pressure was significantly higher in subjects with helicobacter infection before adjustment for age, sex, body mass index (weight $(\mathrm{kg}) /($ height $\left.(\mathrm{m})^{2}\right)$ ), smoking, and high alcohol intake, but significantly lower after these adjustments (see table). No difference was found for diastolic blood pressure. Further analysis after the exclusion of 310 subjects who were taking treatment for previously known hypertension did not change these results significantly.

In multivariable analysis, older age $(4.33 \mathrm{~mm}$ $\mathrm{Hg}$ /decade, $95 \%$ confidence interval 3.76 to 4.89 ), sex (4.1 $\mathrm{mm} \mathrm{Hg}$ higher in men than in women; 3.20 to 4.94), increasing body mass index $(0.74 \mathrm{~mm} \mathrm{Hg}$ per unit, 0.65 to 0.84 ), and high alcohol intake, defined as $>20$ units per week for men and >13 units per week for women (2.64 mm Hg, 1.15 to 4.13), were all associated with a significantly increased systolic blood pressure. Conversely, current use of drugs for hypertension $(-10.48 \mathrm{~mm} \mathrm{Hg},-12.31$ to -8.65$)$ was associated with a significant reduction in systolic blood pressure. Similar associations were found for diastolic blood pressure.

\section{Comment}

Our findings indicate that, contrary to some previous suggestions, the association that exists between cardiovascular disease and $H$ pylori infection is not accounted for by any increase in blood pressure.
$H$ pylori infection had little effect on blood pressure in the general population in the age groups studied when methods designed to minimise potential sampling biases and selection biases were used. Mean systolic blood pressure was higher in $H$ pylori infected individuals than in those who were not infected and, although this is significant statistically, it is unlikely to be clinically important and may be explained by unknown residual confounding factors.

This research was presented at the American Gastroenterological Association meeting in May 2000 and subsequently published in abstract form (Gastroenterology 2000;118 (suppl 2):A723).

Contributors: RH initiated and helped to plan the project, and wrote the initial draft of the paper. AL ran the project from day to day, and helped with the analysis of the data and the final version of the paper. PN helped to set up the project and produce the final version of the paper. $\mathrm{LM}, \mathrm{IH}$, and JD helped to plan the project, analyse the results, and produce the final version of the paper. $\mathrm{RH}$ is the guarantor.

Funding: This study was supported by the South and West Regional Research and Development Directorate and GlaxoSmithKline.

Competing interests: $\mathrm{RH}$ and AL received financial support from GlaxoWellcome UK to attend the American Gastroenterological Association meeting in May 2000.

1 Patel P, Mendall MA, Carrington D, Strachan DP, Leatham E, Molineaux $\mathrm{N}$, et al. Association of Helicobacter pylori and Chlamydia pneumoniae infections with coronary heart disease and cardiovascular risk factors. BMJ 1995;311:711-4.

2 Danesh J, Youngman L, Clark S, Parish S, Peto R, Collins R. Helicobacter pylori infection and early onset myocardial infarction: case-control and sibling pairs study. BMJ 1999;319:1157-62.

3 Barnes RJ, Uff JS, Dent JC, Gear MWL, Wilkinson SP. Long term follow up of patients with gastritis associated with Helicobacter pylori infection. Br J Gen Pract 1991;41:286-8.

4 Whincup PH, Mendall MA, Perry IJ, Strachan DP, Walker M. Prospective relations between Helicobacter pylori infection, coronary heart disease and stroke in middle aged men. Heart 1996;75:568-72.

5 Lip GYH, Wise R, Beevers G. Association between $\mathrm{H}$ pylori infection and hypertension. BMJ 1996;312:250-1.

(Accepted 23 March 2001)
Department of Social Medicine, University of Bristol, Bristol BS8 2PR Athene Lane research associate Liam Murray lecturer in public health medicine Ian Harvey senior lecturer in health services research

Jenny Donovan reader in social medicine

Correspondence to: R Harvey richard.harvey1@ virgin.net

\section{One hundred years ago A modified Hippocratic oath for nurses}

We learn from the Boston Medical and Surgical Journal that the graduating exercises of the training school for nurses at the City Hospital, Blackwell's Island, were held on June 1st. There were fifty-two graduates. A novel feature in the ceremony was the administration of a modified Hippocratic oath to the class. Among the clauses of the oath are the following: "That you will be loyal to the physicians under whom you serve, as a good soldier is loyal to his officers. That whatsoever you shall see or hear of the lives of men and women, whether they be your patients or members of their households, you will keep inviolably secret, whether you are in other households or among your own friends." We are of the opinion of the sensible person in Punch who replied to the fair temperance proselytiser that "people should keep sober without taking hoaths about it." But granting the need of an oath for nurses, the one from which we have quoted seems to be good enough for its purpose. (BMJ 1901;ii:40) 